\title{
ARTIKEL
}

\section{SAATNYA PUSTAKAWAN BERGERAK DI ERA DISRUPTIF}

\author{
Sulistiorini, Dwi Marina, Fahimatun Nafisa, Indah Fatma Silvi \\ Perpustakaan Universitas Airlangga \\ E-mail:Sulis.Syama@gmail.com
}

\begin{abstract}
ABSTRAK
Transformasi perpustakaan dari era konvensional ke digital tanpa disadari membawa pengaruh besar terhadap kinerja pustakawan. Melihat kondisi demikian Kepala Perpustakaan Nasional Muhammad Syarif Bando memotivasi pustakawan di era disruptif dengan slogannya "Pustakawan Bergerak". Maksudnya pustakawan dapat memobilisasi pengetahuan kepada masyarakat agar informasi yang tersimpan, tersedia secara digital dapat disebarluaskan dan mengena kepada masyarakat yang membutuhkannya. Berbagai kegiatan "Pustakawan bergerak" di sini adalah mengoptimalkan sumber daya dan fungsi pustakawan dalam peningkatan sumber daya manusia yang berkompetensi. Metode penulisan artikel ini adalah deskriptif, berdasarkan pengalaman kami sebagai pustakawan di Perpustakaan Perguruan Tinggi Universitas Airlangga Surabaya dan berbagai sumber literatur yang mendukung teori penulisan artikel ini. Harapannya adalah untuk memotivasi para pustakawan akan eksistensinya di era disruptif.
\end{abstract}

Kata kunci: Pustakawan, Disruptif, Kompetensi

\section{PENDAHULUAN}

Di tengah kemajuan Teknologi Informasi dan Komunikasi (TIK) saat ini, perpustakaan perguruan tinggi berusaha untuk membangun dan meningkatkan peradaban manusia. Dengan ketersediaan konten digital, serta sumber daya manusia yang handal dalam penguasaan Teknologi Informasi dan Komunikasi (TIK) menggambarkan perpustakaan perguruan tinggi tidak tinggal diam dalam memenuhi tuntutan pemustaka akan kebutuhan informasinya. Transformasi dari bentuk konvensional ke digital sangat dirasakan oleh para pustakawan saat ini, yang secara tidak langsung berdampak ke tugas pustakawan itu sendiri. Dimana informasi mudah diakses dan didapat secara langsung melalui media internet maupun digital. Apa yang harus dilakukan dan dikerjakan oleh pustakawan saat ini, apakah harus duduk diam tanpa melakukan kegiatan apa-apa. Tuntutan kerja untuk mencapai angka kredit yang ingin dicapai dalam meningkatkan jenjang karier pustakawan harus terpenuhi. Hal ini harus disadari oleh para pustakawan melakukan kreativitas dalam pekerjaan mereka, selain melakukan kegiatan rutinitas di belakang meja juga meningkatkan potensi mereka guna pengembangan diri sebagai pustakawan.
Seperti yang telah dicanangkan oleh Muhammad Syarif Bando, Kepala Perpustakaan Nasional di awal tahun 2018, dengan tag line "PUSTAKAWAN BERGERAK". Harapan Pak Syarif Bando dengan Pustakawan Bergerak dapat memobilisasi pengetahuan (knowledge mobilization) untuk masyarakat. Pustakawan Bergerak merupakan salah satu cara mengoptimalkan sumber daya dan fungsi pustakawan sehingga kualitas sumber daya manusia meningkat sesuai kompetensi yang dimilikinya (Makarim, 2018). Maka dalam sepak terjang "Pustakawan Bergerak" tidak terlepas dari Budaya kerja dan kompetensi, sebagaimana telah dijelaskan dalam RPP (Rancangan Peraturan Pemerintah) tahun 2009 tentang Standar Nasional Perpustakaan Bab V Standar Tenaga pada Pasal 27 disebutkan (Rimbarawa, 2013).

1. Pustakawan harus memiliki kompetensi professional dan kompetensi personal.

2. Kompetensi professional sebagaimana dimaksud pada ayat (1) mencakup aspek pengetahuan, keahlian dan sikap kerja

Untuk itu kami penulis ingin memberikan gambaran dan konsep seperti apa yang dimaksud dengan "Pustakawan Bergerak" yang akan dijelaskan pada artikel ini. Berdasarkan tugas dan pengalaman yang pernah kami lakukan dan kerjakan di Perpustakaan Universitas 
Airlangga Surabaya sebagai tempat kami bekerja. Semoga dengan tulisan ini bisa menambah wawasan dan menimbulkan semangat bekerja untuk para pustakawan baik di semua jenis perpustakaan khususnya perpustakaan perguruan tinggi. Serta eksistensi pustakawan terus berkembang di sepanjang jaman.

\section{TINJAUAN PUSTAKA}

\section{Budaya Kerja Dan Kompetensi Pustakawan Budaya Kerja Pustakawan}

Pustakawan bukanlah tenaga perpustakaan yang berdiri sendiri, melakukan pekerjaan sendiri serta diorganisir sendiri. Memang kenyataannya pustakawan dalam rutinitas pekerjaannya lebih bersifat individual outonomy (Makmur, 2015, hal. 56). Pengertian pustakawan itu sendiri menurut Undang-Undang No 43 tahun 2007 Pasal 1,

Pustakawan adalah seseorang yang memiliki kompetensi yang diperoleh melalui pendidikan dan/ atau pelatihan kepustakawanan serta mempunyai tugas dan tanggung jawab untuk melaksanakan pengelolaan dan pelayanan perpustakaan

Pustakawan tidak berdiri sendiri tetapi dalam suatu organisasi atau lembaga seperti yang dijelaskan dalam SK MENPAN No. 132 KEP/M.PAN/12/2002 pustakawan adalah

Pegawai Negeri Sipil yang diberi tugas, tanggung jawab, wewenang, dan hak secara penuh oleh pejabat yang berwenang untuk melakukan kegiatan kepustakawanan pada unit-unit perpustakaan, dokumentasi dan atau informasi (PERPUSDOKINFO) di instansi pemerintah dan atau unit tertentu lainnya ((Rimbarawa, Kosam (editor), 2013)

Karena pustakawan merupakan sebuah profesi yang mana dalam aktivitasnya tidak terlepas dari budaya kerja. Menurut Makmur budaya kerja adalah sebuah sistem nilai yang diambil maupun dikembangkan oleh sebuah organisasi, yang menjadi aturan dan digunakan sebagai pedoman berfikir dan bertindak untuk mencapai tujuan organisasi. Sebagaimana dikutip oleh Makmur (2015, hal. 13) (http://www.e-dukasi.net, 2009:1) budaya kerja merupakan seperangkat sistem yang terlihat dalam nilainilai kerja, yang diperjuangkan dan diwujudkan dalam satu tatanan manajemen yang baik dan berkualitas. Maka akan tercermin dari sikap perilaku, kepercayaan, cita-cita, pendapat, dan tindakan yang terwujud dalam bekerja. Bilamana budaya kerja dilaksanakan dan diterima dengan baik pada suatu organisasi, hal ini akan dapat mengubah sikap dan perilaku sumber daya manusia yang ada di organisasi tersebut dalam mencapai produktivitas kerja yang lebih tinggi.

Budaya kerja pustakawan tidak terbentuk begitu saja, diperlukan waktu yang cukup lama untuk tercapainya keselarasan budaya kerja pustakawan dengan tujuan organisasi. Untuk itu diperlukan manajemen perpustakaan yang ideal yang tidak bisa dipisahkan dengan dukungan budaya kerja. Dan jelas kegiatan-kegiatan di organisasi harus didukung oleh budaya kerja.

Banyak kesamaan pendapat ahli yang mendefinisikan tentang unsur-unsur budaya kerja. Makmur (2015, hal. 16-17) menyimpulkan ada tiga unsur budaya kerja yang harus diterapkan oleh perpustakaan dalam mencapai visi dan misi organisasi perpustakaan tersebut. Ke-tiga unsur budaya kerja tersebut yaitu

1. Pustakawan dalam organisasi. Organisasi adalah sebuah lembaga yang memiliki keteraturan yang diwujudkan dalam susunan hierarki, pekerjaanpekerjaan, tugas-tugas, wewenang dan tanggung jawab, sistem penggajian (Reward System) dan sistem pengendalian.

Namun kenyataannya, masih banyak pustakawan yang belum memahami secara detail tentang koordinasi wewenang dan tugas dalam bekerja. Hal ini dikarenakan, belum dioptimalkan secara menyeluruh koordinasi kerja dan komunikasi di perpustakaan. Jika pustakawan belum atau tidak memahami struktur organisasi, maka dapat dibayangkan pekerjaan tidak terlaksana dengan baik oleh pustakawan dalam menjalankan tugas, wewenang, dan tanggungjawab. Selanjutnya ketika pekerjaan tidak terlaksana dengan baik, secara tidak langsung akan berdampak pada budaya kerja, sedangkan struktur merupakan aspek mendasar yang dapat menjadikan pedoman tentang garis tanggung jawab serta akuntabilasi dalam menjalankan job description (2015, hal. 23).

2. Pustakawan sebagai relasi. Yang dimaksud dengan relasi merupakan sistem yang dinamis yang dapat mempengaruhi keseluruhan tingkah laku individuindividu yang ada dalam organisasi sehingga mempengaruhi cara organisasi dalam berinteraksi dan bekerja. Pada dasarnya relasi kerja organisasi menggambarkan kemampuan tingkat risiko anggota organisasi terhadap konflik yang dilakukan melalui proses toleransi. Risiko adalah karakteristik dari keputusan tentang ketidakpastian apakah berpotensi signifikan atau mengecewakan dari hasil keputusan yang akan terwujud. Sedangkan toleransi terhadap 
risiko itu sendiri menurut Rivai yang dikutip oleh Makmur (2015, hal. 46) adalah salah satu faktor yang mempengaruhi sikap pengambilan risiko dalam kemampuan pengambilan keputusan, selain faktor keterampilan kerja, pendidikan, intelegensi, lingkungan kerja, rasa aman. Untuk pengertian konflik dalam relasi ini yaitu adanya rasa ketidakcocokan antara individu atau kelompok dalam mencapai sebuah tujuan organisasi yang didorong oleh kesalahpahaman, rasa iri, tidak ada koordinasi yang jelas, kurangnya komunikasi, perbedaan tujuan dan pendapat atau hal lainnya. Ketika terjadi konflik dalam organisasi tersebut maka perlu adanya kerjasama, koordinasi dan mediasi agar dapat mengurangi atau mencegah terjadinya konflik pada suatu organisasi.

3. Pustakawan sebagai individu. Yang dimaksud dengan unsur sebagai individu dimana pustakawan memiliki kemampuan, kepercayaan diri, pengharapan kebutuhan dan karakteristik yang akan dibawa dalam suatu organisasi. Hal ini harus disadari oleh organisasi perpustakaan itu sendiri bahwa setiap pustakawan sebagai individu memiliki karakteristik yang berbeda antara pustakawan yang satu dengan lainnya. Sikap dan kemampuan yang dimiliki pustakawan tercermin dalam perilaku pustakawan pada saat bekerja. Pustakawan sebagai individu memiliki otonomi individu (individual autonomy) untuk melaksanakan tugas organisasi. Sebagaimana yang dikemukakan oleh Flippo (Makmur, 2015, hal. 56) individual autonomy adalah kewajiban seseorang untuk melaksanakan fungsi-fungsi yang ditugaskan dengan sebaik-baiknya sesuai dengan pengarahan yang diterima. Yang mana individual autonomy tidak hanya berpaku pada pekerjaan saja tetapi juga tanggung jawab berupa kepercayaan yang diberikan sebagai orang yang mempunyai potensi. Pekerjaan otonomi individu sering dikaitkan dengan motivasi yang akan menumbuhkan produktivitas lebih tinggi atau efektivitas.

Konseptual otonomi individu secara idealnya dapat dilihat dalam dua tingkatan berhubungan yang terpisah:

1. Berhubungan dengan profesional individu

Otonomi individu pustakawan dapat diartikan sebagai hak, wewenang dan kewajiban pustakawan dalam mengatur dan mengurus pekerjaannya sendiri sesuai dengan peraturan dan norma yang berlaku dalam organisasi

2. Berhubungan dengan profesi

Hakikat otonomi individu di perpustakaan adalah mengembangkan pustakawan yang otonomi, pimpinan memberi keluasan bagi pustakawan untuk melihat potensi-potensi yang dimiliki setiap individu secara optimal.

Namun dalam kenyataannya banyak pustakawan belum merasakan dan mendapat hak atau wewenang yang sama dalam otonomi individu. Pada dasarnya dikarenakan tidak adanya aturan yang jelas siapa-siapa saja harus mendapat kesempatan tersebut baik untuk jangka pendek maupun panjang, transparansi informasi dan komunikasi. Maka untuk tercapainya tujuan organisasi diperlukan komunikasi yang intensif dan berkelanjutan antara pustakawan dan manajemen, agar tidak terjadi kesalahpahaman dengan otonomi individu yang telah diterapkan selama ini.

\section{Kompetensi Pustakawan}

Sebagaimana telah dijelaskan di atas dalam Undang-Undang No. 43 Tahun 2007 bahwa pustakawan saat ini di era disruptif, harus memiliki kompetensi. Artinya pustakawan dituntut untuk lebih meningkatkan profesionalismenya sesuai dengan pendidikan dan/ atau pelatihan kepustakawanan yang telah dicapainya. Serta sebagai tolak ukur untuk mengetahui sejauh mana kemampuan pustakawan menggunakan pengetahuan dan keterampilan yang dimilikinya dalam melaksanakan suatu pekerjaan. Perpustakaan bukan tempat untuk pegawai buangan atau malas, akan tetapi pegawai yang mampu mengelola dan mengembangkan perpustakaan. Apalagi di era disruptif, informasi mudah dapat diakses dan diterima secara mudah dan langsung melalui media internet. Dengan melihat kondisi tersebut akankah pustakawan membiarkan pemustaka (pengunjung, pemakai dsb.) kemana-mana ((Rimbarawa, Kosam (editor), 2013, hal. 84)).

Pustakawan dengan kompetensinya, bagaimana menjaring, menyaring, mengakses, mengeksplore, mengklasifikasi, mengkaji dan yang utama bagaimana informasi tersebut dapat temu kembali secara mudah oleh pemustaka. Untuk itu diperlukan komitmen dan kompetensi pustakawan sebagai penyelenggara perpustakaan agar dapat memenuhi harapan masyarakat pemustakanya. Dengan harapan perpustakaan berperan aktif dalam mencerdaskan kehidupan bangsa menuju masyarakat yang cerdas dan pembelajar (learning society).

Dengan adanya kompetensi pustakawan tersebut, pustakawan memperoleh sebuah "Pengakuan" yang tertulis dalam sertifikat kompetensi. Sertifikat kompetensi adalah proses pemberian sertifikat kompetensi yang 
dilakukan secara sistematis dan objektif melalui uji coba kompetensi yang mengacu pada standar kompetensi kerja baik yang bersifat nasional, khusus maupun internasional (Rimbarawa, Kosam (editor), 2013, hal. 82))

Jenis pekerjaan di era konvensional dengan disruptif sangat dirasakan berbeda jauh. Seperti apa dan bagaimana pekerjaan pustakawan saat ini yang penuh tantangan dengan kemajuan Teknologi Informasi dan Komunikasi (TIK). Menurut Shapiro dan Hughes (1996) yang dikutip oleh Pendit (2007) dalam buku (Makmur, 2015, hal. 64) ada tujuh kemampuan yang menjadi persyaratan dan harus dimiliki pustakawan dalam era disruptif yaitu:

1. Tool literacy, yaitu kemampuan pustakawan dalam memahami dan menggunakan alat teknologi informasi, baik secara konseptual maupun praktikal serta keterampilan menggunakan perangkat lunak, perangkat keras, multimedia dan sebagainya.

2. Resource literacy, yaitu kemampuan pustakawan memahami bentuk, format, lokasi, dan cara mendapatkan informasi terutama dari jaringan informasi yang selalu berkembang.

3. Social-structural literacy, merupakan pemahaman yang benar bagaimana informasi dihasilkan oleh berbagai pihak dalam masyarakat.

4. Research literacy, yaitu kemampuan pustakawan menggunakan peralatan berbasis teknologi informasi sebagai alat riset.

5. Publishing literacy, kemampun pustakawan menerbitkan informasi dan ide ilmiah ke kalangan luas dengan memanfaatkan komputer dan internet.

6. Emerging technology literacy, kemampuan pustakawan secara kontinyu (terus menerus) dalam menyesuaikan diri dengan perkembangan teknologi dan bersama komunitasnya menentukan arah pemanfaatan teknologi informasi untuk kepentingan pengembangan ilmu.

7. Critical literacy, kemampuan pustakawan dalam mengevaluasi secara kritis terhadap untung ruginya menggunakan teknologi telematika dalam kegiatan ilmiah.

Kompetensi pustakawan tidak sampai di situ saja, menurut McNeil dan Giesecke menambahkan kompetensi inti yang harus dimiliki oleh pustakawan dikutip oleh makmur (2015, hal. 65), yaitu:

1. Analytical skills/Problem solving/Decision Making, kemampuan pustakawan dalam menganalisis, memecahkan masalah dan mengambil keputusan dalam segala permasalahan yang ada di lingkungan kerjanya.
2. Communication skills, kemampuan pustakawan dalam berkomunikasi, menyampaikan informasi kepada pemustaka maupun masyarakat luas tentang perpustakaan itu sendiri maupun keilmuwannya.

3. Creativity/innovation, kemampuan pustakawan dalam mengembangkan ide dan gagasan yang tertuang dalam pekerjaannya baik secara organisasi maupun pengembangan dirinya.

4. Expertise and Technical knowledge, kemampuan pustakawan dalam penguasaan teknologi informasi dan komunikasi baik secara teknis maupun operasional.

5. Flexibility/adaptability, kemampuan pustakawan untuk beradaptasi dan bekerja secara efisien dalam situasi yang berbeda baik secara berkelompok maupun individu.

6. Interpersonal/Group Skills, kemampuan atau keterampilan yang melekat pada pustakawan baik secara individu maupun kelompok, yang dinyatakan dalam tampilan sikap, tingkah laku dan perbuatan yang mencerminkan keakuratan dalam menunjang pelaksanaan tugas.

7. Leadership, kemampuan pustakawan dalam memimpin sebuah organisasi besar atau kecil.

8. Organizational Understanding and Global Thinking, kemampuan dan pemahaman pustakawan terhadap organisasi dan berpikir secara luas (global).

9. Ownership/Accountability/Dependability, kemampuan pustakawan rasa memiliki, bertanggungjawab akan informasi yang disebarkan ke pemustaka maupun masyarakat secara luas.

10. Planning and Organizational skills, kemampuan pustakawan dalam perencanaan kegiatan organisasi maupun individu dalam menunjang pelaksanaan tugas.

11. Resource management, kemampuan pustakawan dalam mengadakan, menghimpun, mengolah, menyimpan dan menyebarkan informasi kepada pemustaka maupun masyarakat luas.

12. Service Attitude/user satisfaction, kemampuan pustakawan memberikan pelayanan kepada pemustaka secara service excellent (senyum, sapa, dan bantu).

Syarat-syarat kompetensi diatas tidak serta merta muncul begitu saja pada diri pustakawan sebagaimana yang telah dijelaskan diatas bahwa pustakawan secara pribadi memiliki karakteristik yang berbeda baik dari skills (kemampuan) dan pengetahuan. Sering dijumpai dalam pustakawan itu sendiri rasa keengganan dalam meningkatkan pengembangan dirinya dengan berbagai 
alasan yang disampaikan. Sehingga berdampak pada kenaikan pangkat yang tertunda atau Diberhentikan Sementara (DBS) bahkan ada yang beralih ke jabatan struktural. Hal ini tidak akan terjadi bilamana kita menyadari peran kita sebagai pustakawan dan dukungan dari sebuah organisasi tersebut. Maka perlu adanya sebuah penguatan atau dukungan dalam diri pustakawan dan organisasi akan pustakawan. Ada beberapa strategi yang perlu diperhatikan dan harus dijalankan oleh organisasi dalam pengembangan kompetensi pustakawan itu sendiri, yaitu

1. Penguatan SDM (Social Architecture)

Perpustakaan sebagai sebuah lembaga atau organisasi harus memberikan dukungan secara rasional dan proporsional (seimbang, adil, dan merata) kepada pustakawan terhadap TUPOKSI yang ditugaskan. Strategi penguatan SDM itu sendiri yaitu

a. Penyusunan standar kompetensi pustakawan, pustakawan yang dianggap kompeten harus melalui uji kompetensi dan dibuktikan dengan sertifikasi

b. Peningkatan kompetensi pustakawan:

- Menyelenggarakan diklat bidang kepustakawanan dengan kurikulum yang selalu mengikuti perkembangan dunia TIK

- Mengikutsertakan pustakawan dalam kegiatan atau pertemuan ilmiah

- Mengikutsertakan pustakawan dalam kegiatan magang atau on the job training

- Mengikutsertakan pustakawan dalam studi banding baik ke perpustakaan dalam maupun luar negeri

- Memberikan reward berupa tunjangan sesuai dengan kompetensinya

Peningkatan kompetensi pustakawan di era disruptif sangat diperlukan karena

- Perubahan paradigm perpustakaan, yang sifatnya dari konvensional ke arah perpustakaan yang modern. Maka program pengembangan SDM harus merupakan program prioritas agar tidak tertinggal jauh oleh daerah lain

- Peningkatan profesionalisme tim penilai, profesionalisme tim penilai menjadi syarat mutlak agar hasil penilaiannya dapat dipertanggungjawabkan secara kualitas.

2. Penguatan Teknologi Informasi dan Komunikasi/TIK (Technological Architecture)

Untuk memenuhi kebutuhan pemustakanya akan informasi dan meningkatkan layanan yang luas dan baik kepada pemustaka, perpustakaan harus dapat beradaptasi, mengikuti, dan menguasai TIK. Ketersediaan TIK diharapkan dapat memberikan dan kemudahan akses informasi secara cepat dan tepat bukan hanya sarana prasarana saja (Rimbarawa, Kosam (editor), 2013).

Berkaitan dengan kompetensi pustakawan, selain tugas utama atau pokok yang harus dikerjakan oleh pustakawan dalam profesinya baik itu mengadakan, menghimpun, mengolah, menyerbarluaskan dan melayani informasi kepada pemustaka. Ada beberapa kegiatan yang dapat dilakukan pustakawan dalam meningkatkan pengembangan potensinya. Hal ini dapat disesuaikan dengan kondisi (kemampuan dan pengetahuan) pustakawan maupun organisasi (perpustakaan) sebagai pendukung kegiatan perpustakaan tersebut. Maka untuk tercapainya kompetensi pustakawan dibutuhkannya sebuah "Komitmen" antara organisasi (perpustakaan) dengan pustakawan atau sebaliknya pustakawan dengan organisasi (perpustakaan).

\section{METODE PENELITIAN}

Artikel ini ditulis oleh penulis berdasarkan teori yang ditemukan dari beberapa literatur, pengamatan, dan pengumpulan data-data yang diperoleh dari sumber media sosial serta kegiatan-kegiatan pustakawan yang relevansi di era disruptif saat ini.

\section{PEMBAHASAN}

\section{Pustakawan Bergerak}

Seperti yang telah disampaikan dan digaungkan oleh Bapak Muhammad Syarif Bando di atas bahwa pustakawan di era disruptif saat ini adalah pustakawan bergerak. Kami mendefinisikan pustakawan bergerak adalah pustakawan yang tidak hanya duduk diam di belakang meja dan melakukan kegiatan rutinitas sehari-hari. Tetapi kita dapat mengeksplor potensi yang kita miliki melalui berbagai kegiatan yang dilakukan di luar kerja rutinitas kita. Ruang lingkup pustakawan bergerak di sini dan berdasarkan pengalaman yang pernah kita lakukan di Perpustakaan Universitas Airlangga Surabaya, antara lain:

\section{Menulis}

Dalam Peraturan Kepala Perpustakaan Nasional Republik Indonesia Nomor 11 tahun 2015 tentang 
Petunjuk Teknis Jabatan Fungsional Pustakawan dan Angka Kreditnya di tabel rincian kegiatan pustakawan disebutkan menulis adalah salah satu kegiatan pengembangan profesi (Indonesia, 2016). Maka tidak salahnya pustakawan untuk membuat karya tulis/karya ilmiah baik dalam bentuk buku, makalah, atau jurnal dan dapat dilakukan secara individu (perorangan) maupun berkelompok. Sekarang ini banyak kegiatan perpustakaan baik yang dilakukan oleh perpustakaan perguruan tinggi maupun badan perpustakaan lainnya yang mendukung atau menjembatani kegiatan pustakawan itu sendiri, misalnya call for paper. CFP merupakan kegiatan conference atau seminar ilmiah yang menghadirkan para profesi pustakawan, dosen, mahasiswa, maupun stakeholders untuk berbagi informasi melalui makalah yang dipresentasikannya. Pustakawan Perpustakaan Universitas Airlangga diberi kesempatan untuk mengembangkan kreativitas menulis di Jurnal Perpustakaan Universitas Airlangga yang terbit tiap tahun. Serta kita juga mendatangkan narasumber untuk memberikan kiat-kiat menulis untuk pustakawan itu sendiri yang diadakan oleh Kelompok Pustakawan Perpustakaan Universitas Airlangga.

\section{Pengertian, Manfaat, dan Langkah-langkah menulis}

Dari sejak kecil sebelum pra sekolah (TK) kita diajarkan oleh guru maupun orang tua belajar mengeja huruf dan angka maupun menulis. Mungkin sampai usia kita belum dipanggil Yang Maha Kuasa dan masih diberi kesehatan, kita tidak terlepas dari kegiatan menulis baik itu di secarik kertas, buku maupun alat elektronik (laptop, hand phone). Kita sering melakukan kegiatan menulis dan belum mengerti apa yang dimaksud dengan menulis itu. Menurut Nurhadi (2017, hal. 5) menulis adalah kegiatan melahirkan ide dan mengemas ide itu ke dalam bentuk lambing-lambang grafis berupa tulisan yang dapat dipahami oleh orang lain. Jadi produk menulis adalah sebuah tulisan yang digunakan untuk mengekspresikan diri dan mengkomunikasikan ide kepada orang lain secara tidak langsung.

Sedangkan apa manfaat menulis bagi pustakawan?, Mursyid (2015, hal. 15-17) ada lima manfaat yang dapat diperoleh pustakawan melalui menulis yaitu:

1. Psikologis. Berkaitan dengan eksistensi pustakawan. Dimana menjadi kebanggaan tersendiri bagi pustakawan, dapat menyumbangkan ide dan gagasan kepada orang lain melalui tulisannya.
2. Sosiologis. Melalui tulisannya tersebut, pustakawan telah berkontribusi memberikan solusi terhadap suatu permasalahan baik yang dalam lingkup profesinya maupun di luar profesinya.

3. Ekonomis. Tulisan yang telah terbit baik dalam bentuk buku, makalah, jurnal tidak hanya sekedar diterbitkan begitu saja tetapi juga memiliki nilai lebih dalam bentuk reward (uang). Biasanya diterbitkan dalam media massa akan diberikan reward secara langsung, bisa juga diberikan oleh organisasi (perpustakaan) bilamana telah terjadi komitmen antara organisasi dengan pustakawan. Dan ini menjadi pemacu semangat pustakawan untuk menulis.

4. Keilmuwan. Melalui menulis kita tidak hanya sekedar menuangkan ide dan gagasan kita saja tetapi juga mengukur sejauh mana keilmuwan yang kita miliki. Seberapa banyak buku yang sudah kita baca dan seberapa mampu menuangkannya ke dalam sebuah tulisan dan dipahami oleh banyak orang.

5. Dokumentasi. Dengan menulis bahwa kita telah mendokumentasikan suatu hal atau peristiwa. Misalnya peristiwa sejarah. Tanpa adanya sebuah tulisan maka sejarah akan bisu dan perlahan hilang.

Selain ke-lima manfaat menulis di atas, kami juga menambahkan manfaat menulis ditinjau dari sisi kinerja (prestasi kerja) pustakawan karena menulis adalah salah satu kegiatan pengembangan profesi, memperoleh angka kredit sesuai dengan jabatan pustakawan.

Kegiatan menulis di kalangan pustakawan merupakan kegiatan yang kurang diminati oleh pustakawan karena banyak faktor yang mempengaruhi seperti disibukkan dengan kegiatan rutinitas di perpustakaan, kehabisan ide, tidak ada waktu (urusan keluarga), kurang percaya diri, karangannya tidak menarik, takut salah, malas, dan sebagainya

\section{Menulis Artikel}

Penulisan artikel merupakan kegiatan produktif yang sering dilakukan oleh pustakawan dalam kinerja pustakawan. Artikel dapat dimuat dalam jurnal yang diterbitkan oleh organisasi perpustakaan itu sendiri maupun instansi lain. Sebelum jauh kita membahas jenis-jenis artikel dan sistematika penulisannya maka kita perlu mengetahui apa yang dinamakan artikel itu sendiri. Menurut Kamus Besar Bahasa Indonesia (KBBI) online, artikel adalah karya tulis lengkap, misalnya laporan berita atau esai di dalam majalah, surat kabar, dan sebagainya (https://kbbi.web.id/artikel). Sedangkan jenis artikel itu sendiri ada dua jenis yaitu 
- Artikel ilmiah

Menurut Barnawi (2017, hal. 140) artikel ilmiah adalah karangan nonfiksi yang menjelaskan fenomena sosial dan/atau alam, berdasarkan laporan kegiatan lapangan dan/atau kajian pustaka untuk mencari kebenaran, ditulis sesuai dengan aturan media yang menerbitkannya.

Ciri-ciri artikel ilmiah:

1. Logis, objektif, dan sistematis

Bersifat logis artinya artikel ilmiah ditulis dengan dasar yang masuk akal dan dapat diuji kebenarannya. Objektif, artikel ilmiah tersebut menyajikan fakta atau data sesuai dengan keadaan yang sebenarnya dan dianalisis secara logis tanpa mengedapankan emosi. Sedangkan sistematis itu sendiri, artikel ilmiah disusun secara teratur dan logis bersifat utuh, menyeluruh dan terpadu.

2. Singkat, jelas, dan menarik

Artinya singkat bahwa artikel ilmiah ditulis dengan kalimat yang tidak bertele-tele. Jelas artinya bahwa artikel ilmiah mudah untuk dimengerti. Contohnya tidak menggunakan kata-kata ambigu atau menggunakan kalimat yang berputar-putar.

Sedangkan artikel ilmiah itu sendiri ada dua macam yaitu

1. Artikel hasil penelitian

Merupakan artikel yang ditulis berdasarkan temuan atau hasil dari serangkaian kegiatan penelitian

2. Artikel konseptual

Ditulis berdasarkan hasil pemikiran seorang ahli yang berupa gagasan atau analisis kritis suatu topik

Bahwa kedua jenis artikel di atas dapat dipublikasikan di jurnal ilmiah dan media massa. Jika dipublikasikan di jurnal ilmiah, segala ketentuan dalam jurnal yang dituju harus dipatuhi. Sebab tidak semua jurnal memiliki aturan yang sama. Sebagian besar jurnal ilmiah lebih mengutamakan artikel hasil penelitian. Sedangkan dipublikasikan di media massa setiap artikel harus ditulis dengan menggunakan bahasa yang popular agar mudah dipahami masyarakat umum. Biasanya tematema yang paling aktual dan menarik yang sering dimuat di media massa.

- Artikel ilmiah populer

Adalah sebuah tulisan yang berisi gagasan ilmiah, tetapi disampaikan secara populer. Populer maksudnya ditulis dengan bahasa dan gaya yang mudah dimengerti oleh pembaca awam. Biasanya media terbitnya seperti surat kabar, majalah keluarga, majalah umum, atau jenis serial lainnya. Sedangkan ilmiah sendiri bahwa dalam artikel tersebut isinya merupakan temuan ilmiah dan disajikan secara informasi ilmiah. Namun kemasannya populer (Nurhadi, 2017).

\section{Public Speaking}

Menurut Mustamu public speaking (2012, hal. 210) adalah sebuah kemampuan untuk mengekspresikan gagasan dihadapan publik melalui kompetensi berpidato. Kegiatan public speaking di kalangan profesi pustakawan tidak hanya berpidato saja tetapi juga menjadi narasumber dalam sebuah pelatihan, seminar, sosialisasi, menyampaikan makalah CFP (call for paper). Public speaking tidak semua orang dapat melakukannya dengan baik sebagaimana telah dijelaskan di atas setiap individu mempunyai karakteristik yang berbeda-beda. Sering kita jumpai beberapa narasumber ada yang merasa gugup bahkan demam panggung di saat menyampaikan makalahnya. Hal tersebut menjadi tantangan pustakawan dalam pengembangan communication skills, maka dalam tulisan ini kami ingin memberikan solusi atas permasalahan yang dihadapi pustakawan kompetensi public speaking.

Pustakawan baik di lingkungan perpustakaan sekolah, perpustakaan perguruan tinggi, perpustakaan umum maupun khusus, sering melakukan kegiatan public speaking untuk pengenalan perpustakaan kepada para pemustakanya. Public Speaking sering dilakukan Pustakawan Perpustakaan Universitas Airlangga dalam berbagai kegiatan seperti sharing Online Research Management (ORM), Program Pengenalan Perpustakaan pada Mahasiswa Baru (P3MB), narasumber dalam seminar, forum call for paper (CFP), kelompok pustakawan.

Tugas pustakawan menjadi narasumber mendapatkan point angka kredit sebagaimana telah ditetapkan dalam Peraturan Kepala Perpustakaan Nasional Republik Indonesia Nomor 11 tahun 2015 tentang Petunjuk Teknis Jabatan Fungsional Pustakawan dan Angka Kreditnya (Indonesia, 2016).

\section{Cara mengatasi rasa gugup atau demam panggung}

Sebelum kita presentasi ada rasa gugup, ketidaksanggupan, atau demam panggung pada diri kita. Terlebih bagi kita pertama kali diberikan tugas untuk berpresentasi. Banyak referensi yang memberikan gambaran bagaimana mengatasi rasa kegugupan atau demam panggung di saat presentasi. 
1. Wajar untuk Menjadi Cemas

Tubuh manusia beraksi terhadap semua ancaman dengan respons fisik, psikologis, dan emosional. Jika tubuh kita tidak merasakan atau melakukannya, itu menjadi masalah yang serius

2. Anda Tidak Sendiri

Tanamkan pada diri Anda bahwa Anda tidak sendiri ketika berada di atas panggung atau di depan audiens. Kita semua berada di sini bersama-sama. Semua orang pasti merasakan atau mengalami demam panggung baik sebelum, selama maupun sesudah pidato atau presentasi. Tak ada seorang pun dalam audiens Anda yang tidak akan merasakan demam panggung jika dia berada di tempat Anda, jadi usahakan tetap berani dan percaya diri.

3. Anda Tampak Jauh Lebih Rileks daripada yang Anda Rasakan

Sikap rileks harus Anda tampilkan untuk mengurangi rasa gugup pada diri Anda di saat presentasi. Oleh karena itu dibutuhkan sebuah "keyakinan" bahwa Anda bisa presentasi atau pidato, yang akan membawa Anda pada sebuah kesuksesan dalam melakukan presentasi.

4. Miliki Sesuatu yang Penting untuk Katakan Kutipan seorang tokoh dapat Anda jadikan motivator dalam persiapan berpresentasi. Seperti Abraham Lincoln,

"Aku tak akan pernah cukup tua untuk berbicara tanpa rasa malu ketika aku tak punya sesuatu untuk dibicarakan"

Berbicaralah hanya jika Anda memiliki sesuatu yang penting untuk dikatakan. Hal ini menjadi dasar atau kaidah umum untuk berbicara di depan umum maupun kehidupan sehari-hari.

5. Konsentrasi pada Apa yang Disampaikan

Usahakan lebih berkonsentrasi pada ide utama yang akan Anda bagikan pada audiens daripada pengaturan kata-kata untuk pesan Anda. Jadi jangan terpaku pada detail pidato tetapi lebih fokuskan pada ide pidato atau materi makalah.

6. Latih pidato Anda

Sedikit sekali pembicara yang mampu memberi pidato atau menyampaikan materi makalah yang bagus dan spontan, tanpa latihan terlebih dahulu. Latihan adalah salah satu faktor yang paling penting dalam berpidato dengan penuh percaya diri bagi pembicara pada semua tingkat pengalaman. Tak ada pengganti untuk melatih pidato Anda yang sebenarnya dengan posisi berdiri. Perlu diingat, berbicara di depan umum adalah kemampuan fisik sekaligus kemampuan intelektual dan psikologis.

7. Lepaskan Ketegangan Anda sebelum Anda Berbicara

Salah satu cara mengurangi rasa ketegangan pada diri Anda sebelum tampil berbicara adalah bernafas dalam-dalam dari perut Anda. Cukup dengan bernafas dalam-dalam secara teratur. Anda akan merasakan seluruh irama tubuh Anda menjadi tenang dan terpusat (Fujishin, 2009).

\section{Persiapan Materi}

Materi merupakan senjata utama yang harus dipersiapkan sebaik-baiknya oleh pembicara atau pemateri. Secara umum materi pidato atau presentasi terbagi dalam tiga bagian yaitu:

1. Pembukaan (introduction)

Ada beberapa cara yang dapat dilakukan agar pembukaan pidato atau materi kita bisa menarik perhatian audiens. Kata-kata pembukaan dalam memulai pembicaraan setidaknya memiliki tiga fungsi, yaitu supaya

a. audiens memiliki gambaran umum materi yang akan disampaikan. Jika pembukaan disusun dan diatur dengan baik akan menjadi magnet awal untuk menarik perhatian audiens. Dengan waktu 5 menit pertama sangat menentukan bagaimana situasi Anda selanjutnya.

b. Audiens tahu tujuan pembicaraan. Audiens hadir dalam sebuah forum dengan sebuah tujuan. Dengan kalimat pembukaan dapat menjadi media yang tepat untuk mengemukakan secara gambling pidato atau presentasi Anda.

c. Membangun rasa ingin tahu audiens. Kehadiran audiens di forum tersebut memiliki motif yang berbeda-beda. Dan mereka juga memiliki latar belakang yang berbeda sehingga dengan sebuah kalimat pembuka dapat menjadi sarana efektif untuk membangun rasa ingin tahu terhadap materi yang disampaikan.

Pembicara atau pemateri dapat melakukan beberapa cara dalam pembukaan pidato atau presentasi yang baik, antara lain

a. Membuka dengan sebuah pertanyaan, meminta audiens untuk berpikir dan membuat energi mereka mengalir keseluruh tubuh. Ini cara yang ampuh untuk mendapatkan perhatian audiens secara cepat dan mendapatkan atensi dari mereka. 
b. Membuka dengan kutipan (quotes), kutipan tokoh terkenal dapat juga sebagai pembuka yang dapat menginspirasi para audiens.

c. Membuka dengan cerita, bisa menceritakan pengalaman pribadi atau orang lain bisa berupa cerita humor atau pengalaman dramatis. Asal sesuai dengan topik materi yang disampaikan.

d. Membuka dengan data, data dan fakta statistik dari kehidupan sehari-hari.

e. Membuka dengan humor, dapat dilakukan untuk memancing perhatian audiens dan mengusir rasa ngantuk jam siang di saat konsentrasi audiens menurun atau mulai terpecah

f. Membuka dengan outline, pembicara atau pemateri dapat menyampaikan poin-poin utama materi tujuannya para audiens mendapatkan informasi awal tentang materi apa saja yang ingin disampaikan.

g. Membuka dengan musik/lagu, mungkin ini kurang efektif tapi dapat dilakukan sebelum sesi inti penyampaian materi dimulai

h. Membuka dengan film, bisa dilakukan dengan menampilkan film dokumenter tentang profil organisasi perpustakaannya atau pengalamannya selama menjalankan tugas sebagai sumber pendukung materi yang ingin disampaikan.

2. Batang tubuh (body). Batang tubuh merupakan bagian inti yang ingin disampaikan dalam materi tersebut. Agar para audiens yakin terhadap materi yang disampaikan harus ada data pendukung. Misalnya teori, data atau pendapat yang dapat dijadikan dasar dalam membangun argumentasi yang kuat tetapi harus dilakukan secara bijak agar dapat dicerna dengan baik oleh audiens.

3. Kesimpulan (Conclusion). Menyimpulkan inti pembicaraan dengan me-review poin-poin utama dengan pernyataan yang berkesan (memorable statement). Biasanya dilakukan oleh pembicara handal yang sengaja menyajikan beberapa "misteri" bagi para audiens-nya di ujung pidato atau presentasinya (Sadat, 2015).

\section{Resensi}

Pustakawan Perpustakaan Universitas Airlangga telah mengembangkan kegiatan menulis resensi bukubuku yang dimiliki oleh Perpustakaan Universitas Airlangga baik itu buku baru maupun yang belum pernah diresensikan. Kemudian hasil resensi itu sendiri diupload di web perpustakaan www.lib.unair.ac.id.
Bagi seorang pemula, memulai untuk menulis merupakan hal yang sangat sulit, namun dimulai dari yang mudah dapat dilakukan dengan menulis resensi. Resensi adalah suatu penilaian terhadap sebuah karya. Karya yang dimaksud disini bisa berupa buku dan karya seni film dan drama. Oleh karena itu masyarakat lebih mudah jika membaca isi dari buku tersebut melalui resensi buku. Ada beberapa tahapan yang harus diketahui oleh peresensi jika ingin meresensi buku, karena dari tahaptahap resensi buku itu dapat mencakup isi dari buku dan informasi yang di sampaikan mewakili isi buku yang telah di resensi, antara lain:

1. Judul

Judul semestinya harus mempunyai kesinambungan dengan isi resensi. Selain itu, judul yang menarik memberikan nilai lebih tersendiri.

2. Menyusun Data Buku

Penyusunan data buku meliputi Judul buku, Pengarang, Penerbit, Tahun terbit beserta cetakannya, Harga buku

3. Isi Resensi Buku

Bagian ini berisi mengenai sinopsis, ulasan singkat buku dengan kutipan singkat dan keunggulan serta kelemahan buku, rumusan kerangka buku dan bahasa yang digunakan.

4. Penutup Resensi Buku

Pada bagian penutup biasanya berisi alasan kenapa buku tersebut ditulis dan kepada siapa buku tersebut ditujukan.

Secara garis besar resensi dibagi menjadi 3 jenis, yaitu:

1. Informatif, disini resensi disampaikan secara singkat dan umum dari keseluruhan isi buku.

2. Deskriptif, yaitu resensi yang membahas secara detail pada setiap bagian atau bab nya.

3. Kritis, yaitu resensi yang mengulas detail buku menggunakan metodologi ilmu pengetahuan tertentu. Isi resensi biasanya objektif dan kritis dalam menilai isi buku.

\section{Liaison librarian}

Dalam Perpustakaan pustakawan berperan sangat penting, sehingga tercantum dalam program Tri Dharma perguruan tinggi yaitu mencakup kegiatan pendidikan dan pengajaran, penelitian, dan pengabdian masyarakat. Oleh karena itu pustakawan di lingkungan perguruan tinggi harus mampu bekerjasama dengan masyarakat akademik seperti dosen, mahasiswa, dan staf universitas lainnya demi tercapainya tujuan perguruan tinggi yang bersangkutan. 
Pengguna yang datang ke perpustakaan kebanyakan adalah mahasiswa untuk mencari literatur sebagai penunjang dalam perkuliahan. Sedangkan jarang sekali dosen atau peneliti yang mau berkunjung ke perpustakaan, mereka cenderung mempunyai perpustakaan pribadi atau membeli sendiri buku-buku yang mereka butuhkan, dan mereka juga lebih suka melanggan jurnal-jurnal yang mereka butuhkan. Sehingga dalam perpustakaan harus ada liaison librarian.

Whatley (2009) menyebutkan Liaison librarian adalah Pustakawan penghubung yang mana menghubungkan antara civitas akademika dengan lingkungan perguruan tinggi yakni dalam bidang akademik. Liaison librarian menjadi mediator untuk semua pengguna dengan sumber informasi yang dimiliki oleh perpustakaan, untuk membantu menemukan literature yang sesuai dengan apa yang dibutuhkan oleh pengguna. Lebih daripada itu, liaison librarian adalah seorang yang secara aktif menjalin komunikasi dengan pengguna dengan melakukan diskusi dan menyediakan waktu konsultasi bagi mahasiswa mengenai kebutuhan mahasiswa terhadap informasi dan sumber-sumber informasi yang berkaitan dengan materi perkuliahan. Sekaligus menjadi pembimbing bagi mahasiswa yang mendapatkan tugas-tugas perkuliahan ataupun saat melakukan belajar mandiri diperpustakaan. Tidak hanya mahasiswa saja, akan tetapi liaison librarian juga membantu dosen dan peneliti untuk mendapatkan literature yang mereka butuhkan.

Dengan adanya liaison librarian dalam perpustakaan sebagai penghubung pengguna yang datang ke perpustakaan akan semakin bervariasi serta pengguna juga merasa puas dengan informasi yang di dapat diperpustakaan.

Menurut Karen Stanley Grigg (2017) untuk membangun program penghubung yang sukses diperlukan beberapa tahapan diantaranya:

- Establishing a new science liaison librarian position liaison librarian membangun ilmu baru melakukan program penghubung dengan memposisikan perwakilan pustakawan pada setiap departemen atau fakultas. Seperti contoh Perpustakaan Universitas Airlangga melakukan pelatihan mendeley pada mahasiswa tingkat akhir dan dosen

- Integrating library instruction into the curriculum Melakukan interaksi pada pihak departemen atau fakultas mengenai kurikulum dan mata kuliah yang diadakan, sehingga perpustakaan bisa mengadakan literatur yang mencakup mata kuliah tersebut dengan cara berkolaborasi dalam pengembangan koleksi.
- Promoting and providing services to students Layanan kepada pengguna tidak hanya memberikan layanan menyediakan informasi literatur yang mereka butuhkan, akan tetapi bisa juga dengan melakukan layanan konsultasi baik konsultasi akademik maupun konsultasi pribadi. Layanan ini untuk mendekatkan pustakawan dengan pengguna agar lebih akrab, sehingga pemikiran tentang pustakawan jahat pada zaman dulu oleh pengguna bisa hilang. Dengan pengguna menganggap kita sebagai teman pengguna tidak segan-segan bertanya dan meminta bantuan pada pustakawan, sehingga pengguna juga bisa enjoy diperpustakaan dan meningkatkan kualitas perpustakaan

- Sustaining your liaison services

Untuk mempertahankan layanan sebagai liaison librarian harus selalu meningkatkan kualitas dan kuantitas yang dimiliki. Selalu up date informasi dan ilmu pengetahuan sehingga dapat melakukan pelayanan yang cepat dan berkualitas.

Seorang pustakawan harus bisa menjadi liaison librarian karena sebagai jembatan komunikasi antara pengguna dengan perpustakaan untuk informasi apa saya yang dibutuhkan, dan juga komunikasi sistem perpustakaan dengan departemen untuk memanfaatkan layanan dan fasilitas yang ada di perpustakaan untuk mengadakan koleksi yang sesuai dengan kurikulum yang ada. Pustakawan Perpustakaan Universitas Airlangga sendiri telah berperan sebagai liaison librarian seperti memberikan library class bagi mahasiswa, bagaimana mengelola jurnal untuk dapat submit ke jurnal internasional, pencarian artikel melalui e-journal yang dilanggan Perpustakaan Unair secara cepat dan tepat, mensitasi artikel. Serta dukungan penelitian bagi dosen dan peneliti untuk menawarkan bantuan mendalam dalam menemukan informasi, termasuk mengidentifikasi sumber daya yang paling relevan untuk digunakan, melalukan promosi tentang keunggulan perpustakaan.

\section{Storytelling}

Dunia anak ditinjau dari aspek perkembangan dan kecerdasannya. Perkembangan ini terkait dengan kondisi, keadaan, dan perkembangan aspek psikologis anak-anak sedangkan kecerdasan ini terkait dengan kemampuan intelektual yang dimiliki anak dalam mengatasi problematika kehidupan. Fase anak-anak adalah fase kunci dan istimewa dalam pertumbuhan dan perkembangan. (Kurniawan, 2016). 
Pustakawan Perpustakaan Universitas Airlangga melakukan kegiatan storytelling sebagai salah satu rangakaian acara Pengabdian Masyakarat (PENGMAS) yang sasarannya pada Taman Baca Masyarakat (TBM) dan PAUD di sekitar Kampus Unair. Tujuannya adalah untuk meningkatkan minat baca sejak usia dini. Pustakawan Perpustakaan Unair tidak hanya melakukan kegiatan rutinitas saja tetapi merasa terpanggil dan bertanggung jawab dalam menumbuhkan minat baca di masyarakat sekitarnya.

Storytelling merupakan teknik atau kemampuan untuk menyampaikan sebuah cerita dengan gaya, intonasi, dan alat bantu yang menarik minat pendengar. Storytelling sering digunakan dalam proses belajar mengajar utamanya pada tingkat pemula atau anak-anak. Teknik ini bermanfaat melatih kemampuan mendengar secara menyenangkan.

Dalam storytelling diperlukan teknik kreatif dari storyteller (pendongeng) dalam mendongeng untuk menumbuhkan kecerdasan kinestik-tubuh anak seperti

- suara (intonasi, menirukan suara-suara dari karakter tokoh misalnya suara ayam, menangis, tertawa)

- gerak tubuh, pendongeng tidak hanya berdiri atau duduk diam saja tetapi merefleksikan tokoh-tokoh yang didongengkan misalnya dengan berjalan

- interaksi, pendongeng harus melakukan kontak mata dengan audience

- mimik wajah, pendongeng harus dapat mengekspresi wajahnya sesuai dengan yang didongengkan

- kecepatan, pendongeng harus dapat menjaga kecepatan atau tempo pada saat storytelling, dengan tujuan audience tidak bosan dalam mendengarkan

- alat peraga, untuk menarik audience dalam storytelling diperlukan alat peraga misalnya boneka tangan, kostum hewan yang lucu

\section{PENUTUP}

"Pustakawan Bergerak" merupakan tugas yang harus dijalankan oleh pustakawan di era disruptif saat ini dan kegiatan-kegiatannya telah ditetapkan dalam Peraturan Kepala Perpustakaan Nasional Republik Indonesia Nomor 11 tahun 2015 tentang Petunjuk Teknis Jabatan Fungsional Pustakawan dan Angka Kreditnya. Dengan angka kredit yang diperoleh tersebut dapat meningkatkan ke-Profesionalisme pustakawan itu sendiri dan secara tidak langsung berdampak pada kinerja. Sehingga tidak ada kenaikan pangkat yang tertunda, DBS (Diberhentikan Sementara) bahkan beralih ke jabatan struktural. Maka untuk tercapainya tersebut perlu adanya perhatian dari organisasi atau perpustakaan maupun lembaga pendidikan (Program Studi Perpustakaan) untuk jangka panjang.

Ditinjau dari organisasi atau perpustakaan lebih intensif mengikutsertakan pustakawannya untuk mengikuti pelatihan-pelatihan yang berkaitan dengan kepustakawanan misalnya penulisan buku, artikel ilmiah, story telling, public speaking. Namun tidak hanya pelatihan saja tetapi juga menambah wawasan dan pengetahuan mereka dengan memberangkatkan mereka ke seminar atau workshop dilakukan secara merata dan bergantian kepada para pustakawannya. Akan menimbulkan rasa kepercayaan diri dan membangkitkan semangat mereka untuk berpartisipasi sebagai narasumber, menulis artikel maupun resensi, serta kegiatan-kegiatan pustakawan lainnya.

Sedangkan untuk jangka panjang dalam dunia pendidikan khususnya Program Studi Perpustakaan perlu adanya kegiatan seminar, call for paper, maupun penelitian di kalangan mahasiswa. Berangkat dari pengalaman tersebut akan melahirkan pustakawanpustakawan siap pakai di lapangan kerja.

\section{DAFTAR PUSTAKA}

Barnawi. 2017. Teknik Penulisan Karya Ilmiah. Jogjakarta: Ar-Ruzz Media.

Fujishin, R. 2009. Smart Public Speaker: Seni Berbicara di Muka Umum. Yogyakarta: BOOKMARKS.

Glossop, K. 2007. Liaising Around: Essentials for a New Liaison Librarian. LIScareer.com.

Grigg, K.S. 2017. Building a successful liaison program from the ground up. Building a successful liaison program from the ground up, 1-4.

https://kbbi.web.id/artikel. (n.d.). Retrieved Januari 10, 2019, from https://kbbi.web.id/artikel.

Indonesia, P.N. 2016. Peraturan Kepala Perpustakaan Nasional Republik Indonesia Nomor 11 tahun 2015 tentang Petunjuk Teknis Jabatan Fungsional Pustakawan dan Angka Kreditnya. Jakarta: Perpustakaan Nasional RI.

Kuncoro, M. 2009. Mahir Menulis Kiat Jitu Menulis Artikel Opini, Kolom, dan Resensi. Jakarta: Erlangga.

Kurniawan, H. 2016. Kreatif mendongeng. Jakarta: Prenada.

Makarim, L. 2018, Feb 08. https://www.perpusnas.go.id/ news-detail.php?lang $=i d \& i d=180218120022 y N s C$ grWa8d. Retrieved desember 18, 2018, from https:// www.perpusnas.go.id/news-detail.php?lang=id\&id= 
180218120022yNsCgrWa8d: https://www.perpusnas. go.id/news-detail.php?lang=id\&id=180218120022yN sCgrWa8d

Makmur, T. 2015. Budaya Kerja Pustakawan di Era Digitalisasi: Perspektif Organisasi, Relasi dan Individu. Yogyakarta: Graha Ilmu.

Mursyid, M. 2015. Be a Writer Librarian. Yogyakarta: Lembaga Ladang Kata.

Mustamu, R.H. n.d.. http://repository.petra.ac.id/16397/1/ Publikasi1_93018_972.pdf. Retrieved January 14, (2019)

Nurhadi. 2017. Handbook of Writing: Panduan Lengkap Menulis. Jakarta: Bumi Aksara.

Rimbarawa, Kosam editor. 2013. Peran IPI dalam Meningkatkan Kompetensi Pustakawan menuju Sertifikasi. Jakarta: Sagung Seto.

Rimbarawa, Kosam editor. 2013. Sertifikasi Profesi Pustakawan Indonesia. Jakarta: Sagung Seto.
Sadat, A.M. 2015. Outstanding Speaking: "Ubah Ketakutan Jadi Kekuatan Anda!’. Jakarta: Mitra Wacana Media.

Whatley, K.M. 2009. New Roles of Liaison Librarian: A Liaison's Perspective. Research Library Issue. 1-3.

Internet

https://kbbi.web.id/artikel. n.d.. Retrieved Januari 10, 2019, from https://kbbi.web.id/artikel.

id.wikipedia.org/wiki/Resensi

Makarim, L. 2018, Feb 08. https://www.perpusnas.go.id/ news-detail.php?lang $=i d \& i d=180218120022 y N s C g r W$ a8d. Retrieved desember 18, 2018, from https://www. perpusnas.go.id/news-detail.php?lang=id\&id=1802181 20022yNsCgrWa8d:

https://www.perpusnas.go.id/news-detail.php?lang=id\&id= $180218120022 y N s C g r W a 8 d$

Mustamu, R.H. n.d.. http://repository.petra.ac.id/16397/1/ Publikasil_93018_972.pdf. Retrieved January 14, 2019 rinpm.blogspot.co.id/p/pokok-pembahasan-1.html 